\title{
Balancing power in co-production: introducing a reflection model
}

\author{
Caroline Ärleskog ${ }^{1,2,5 凶}$, Nicoline Vackerberg ${ }^{1,3,5}$ \& Ann-Christine Andersson (10) 1,4
}

The role and position of users in health and welfare has recently changed to become more active in co-production of care. When more co-production is preferred, challenges related to power need to be considered. In this paper, power is seen as the possibility to influence. The paper focuses on power in co-produced improvement work by introducing a reflection model based on Franzén's power triangle, further developed from improvement coaches' perceptions. First, empirical data from interviews with improvement coaches were analyzed and then the theoretical model was created. Twelve coaches were included in the interviews, all of them with experience of co-production and improvement work within a region in southeast Sweden. By combining the empirical results with the power triangle, a reflection model concerning power dimensions was developed. The results showed the necessity of reflection regarding several power-related factors. Resources were found to be important and depending on contextual settings. Attitudes and perceptions among personnel and users were also vital. To accomplish co-production, the power dimension must be considered, and the power triangle acknowledges different power dimensions and how they affect each other. The model has a systematic character and allows adjustments to the power dimensions within any other context. It can inspire and be used by improvers working with co-production to promote deeper professional and organizational reflection and thereby contribute to new insights on how to balance power in co-producing health and welfare services.

\footnotetext{
${ }^{1}$ Jönköping Academy for Improvement of Health and Welfare, School of Health and Welfare, Jönköping University, Jönköping, Sweden. ${ }^{2}$ Department for Sociology and Work Science, Faculty of Social Sciences, University of Gothenburg, Gothenburg, Sweden. ${ }^{3}$ Qulturum, Center for Learning and Innovation in Healthcare, Region Jönköping County, Jönköping, Sweden. ${ }^{4}$ Department of Care Science, Faculty of Health and Society, Malmö University, Malmö, Sweden.

${ }^{5}$ These authors contributed equally: Caroline Ärleskog, Nicoline Vackerberg. ${ }_{\text {email: caroline.arleskog@gu.se }}$
} 


\section{Background}

$\mathrm{n}$ recent years, the role and position of users in health and social care have changed significantly. Instead of being passive recipients of care, users are active co-producers of health and welfare services (Bovaird, 2007; Karlsson and Börjesson, 2011; Norman, 2015; The National Board of Health and Welfare, 2011). The idea behind this is that co-production will lead to effective change and create value (Boyle and Harris, 2009). Co-production can be defined as a partnership aiming to create, share, and negotiate different forms of knowledge to improve care (Vindrola-Padros et al., 2019). However, this is easier said than done because the relationship between caregivers and users is asymmetric (Kirkegaard and Andersen, 2018; Skau, 2007). Power imbalances as well as caregivers' attitudes and fear of losing power can hinder co-production and allow the asymmetric power relationship to persist (The National Board of Health and Welfare, 2013). The underlying power imbalance needs to be addressed and challenged to create an equal and reciprocal relationship between professionals and users (Thor et al., 2004; UCL Public Engagement Blog, 2020; Vindrola-Padros et al., 2019). It is unclear how this can be actualized in everyday practice. This paper introduces a reflection model, making power relationships visual during co-produced improvement work led by improvement coaches in complex care situations.

\section{Improvement coaches in complex care}

Public health and welfare organizations are complex, meaning that simple and linear relationships are not common. Instead, complex organizations are defined by Glouberman and Zimmerman (2002) as systems that are interdependent, non-linear, and with great variations and tension in the interactions. Therefore, improving care is a difficult task, and research shows that improvement coaches can facilitate the improvement of care (Norman, 2015; Godfrey et al., 2013; Thor et al., 2004). This study is built on perceptions of improvement coaches because they are in a position to promote or block user influence and thus coproduction (Mulvale et al., 2019; Roos, 2009). The contextual adaptation of strategies for users' influence to reach the desired outcome and involvement is seen as an essential part of improvement work (Gibbs, 1988). Improvement coaches need to listen to users and recognize them as individuals and members of a team that takes their desires and experiences as a starting point (The National Board of Health and Welfare, 2013; Batalden, 2018). Co-producing improvement can be even more difficult regarding users with complex care needs (The National Board of Health and Welfare, 2008). Special requirements are imposed on improvement coaches to promote co-production. Previous studies underline a belief that users' abilities to contribute are affected by physical as well as mental limitations (Bagchus et al., 2015; Giertz, 2012; Harnett et al., 2012; Lindquist, 2007; Mulvale et al., 2019; Skau, 2007). There must be an awareness of one's own and others' prejudices. Caregivers must actively work against stigmatization and discrimination, as well as develop attitudes characterized by a belief in the users' ability and potentiality (The National Board of Health and Welfare, 2013). Furthermore, coproduction requires a continuous and open-minded discussion, where individual and structural barriers are considered (Greenhalgh et al., 2011; Söderlund and Gentzel, 2007).

\section{Theoretical power perspective}

User influence is a prerequisite to reach co-production, which in turn assumes the possibility to influence. Therefore, there is a need for awareness of the power dimension (Arnstein, 1969; Batalden, 2018; Rose and Kalathil, 2019; Vindrola-Padros et al., 2019), which can be considered especially important because the aspect of power often remains hidden in favor of the aspect of

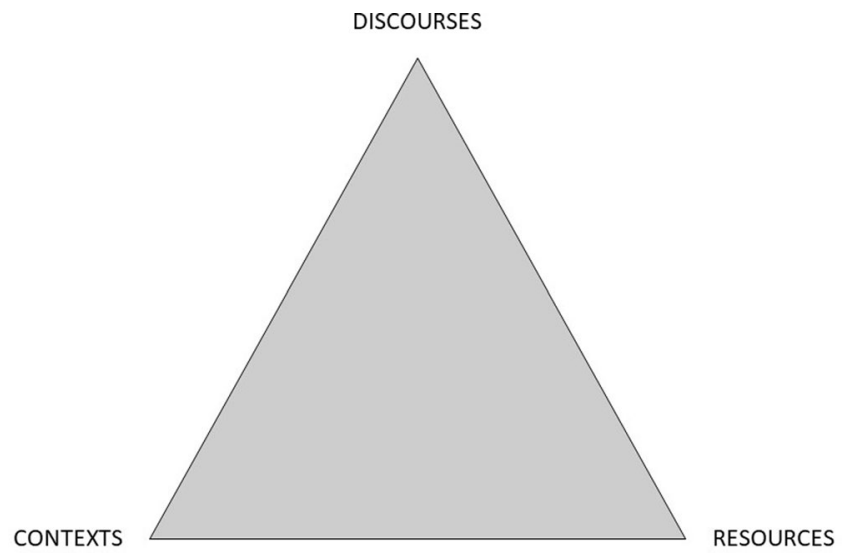

Fig. 1 Franzéns (2010) Power triangle. Used with permission and translated by Ärleskog.

care (Skau, 2007). The relational power perspective can be useful to highlight power relationships. This perspective focuses on the exercise of power rather than on what power is (Lilja and Vinthagen, 2009a). Power is then regarded as something that works through relationships and can be shared, and therefore it is not considered as simply a tool for ruling (Franzén, 2010). Instead, power can be regarded as a complex and multifaceted phenomenon that is constantly present and created in every moment and in every relationship (Lilja and Vinthagen, 2009a). In a relationship, power can be balanced even though it is only temporary. Furthermore, where there is power, there is also a potential resistance (Franzén, 2010). Resistance can be understood as a response to power and can appear in many forms, as an impulsive action, a need, or as a conscious strategy (Lilja and Vinthagen, 2009b). Built on Franzén's (2010) power triangle, this paper describes power in terms of resources, discourses, and contexts (Fig. 1). All three dimensions interact and can be used to study, explain, and understand power.

The relational power perspective considers resources based on relationships, which regulates available resources and affects their strength. Depending on the relationship, the same resource can work differently, which means that resources are something contextual. Discourses can be understood as complex concepts, linking together the meaning of words and images with the beliefs and attitudes they represent. Discourses create conditions for how different phenomena are considered, understood, or taken for granted, such as perceptions that are not being questioned. Finally, contexts enable the identification of central power relations in which power relations can have different meanings and effects in different contexts because they are dynamic rather than static (Franzén, 2010).

\section{Theoretical reflection perspective}

We claim that addressing power is necessary for users to actively influence co-production when improving health and welfare services. This requires constant reflection (Farr, 2018). Reflection is a conscious, will-driven process that takes a larger context into account (Dewey, 1997). It has a systematic and constructive character, unlike everyday thinking, which is associated with a risk that reasoning will be accepted without further reflection. Thinking can then generate hasty or incorrect conclusions. Reflection, however, creates the possibility of visualizing what would otherwise remain unspoken (Pettersson, 2015). Cohglan and Brannick (2001) even describe reflection as "... the critical link between concrete experience, the interpretation and taking new action". Reflection often requires structure and guidance (Pettersson, 2015). Several reflection models have been developed 
(Gibbs, 1988; Moon, 2004; Schön 1983). Models can be beneficial and provide a tool to describe, explain, or analyze abstract and complex phenomena. They can also be enablers of different aspects of a concept and how they interact (Pettersson, 2015). Structured reflection stimulates learning and development for individuals, groups, and organizations (Biguet et al., 2015). We argue that reflection on power is one important part of informing new action regarding co-production for users with complex care needs when improving health and social care. The creation of a reflection model to balance power could then support more equality and contribute to the development of co-production. Therefore, the aim of this paper is to develop, describe, and introduce a reflection model based on improvement coaches' perceptions of power-related conditions, including both enablers and barriers, to achieve better power balance when co-producing and improving care.

\section{Methodology and setting}

This study has a two-fold design. First, empirical interviews were conducted (Ärleskog, 2017). This was followed by conceptualization of a power reflection model.

Setting. In Sweden, health and social care is mainly provided by the public sector. Care is provided by 21 regions and 290 municipalities, with taxation power and a high grade of autonomy. The regions mainly provide health care and the municipalities mainly provide home care, group housing, elderly care, and day care activities. The Highland district, in the south of Sweden, includes six municipalities with a total of 115,000 inhabitants (Central Bureau of Statistics, 2019). The Esther Network started in this area. The philosophy behind the Esther Network is to put the interest of Esther, a figurative persona with complex care needs, at the center at any point in the care chain. Within the Network, hospital care, primary care, and municipality care work together to create the best care for Esther. The Esther Network also includes trained improvement coaches, socalled Esther coaches. The Esther coaches have different professions, mainly nurses, assistant nurses, and social care workers, and they work in hospital wards, in elderly care, or with users with physical, mental, or cognitive disabilities. When the Esther Network started, it was intended for elderly persons, but today the users can be of any age and with any diagnosis, with care needs that involve more than one caregiver organization. The main task of an Esther coach is to carry out improvement work for and with Esther. The overall question guiding the improvement work of the coaches is always: "What is best for Esther?" (Vackerberg et al., 2016).

Participants. The Esther coaches are trained to co-produce improvement work in complex health and social care settings. The first part of this study is based on interviews with those coaches. A strategic sample of interviewees was used (Henricsson and Billhult, 2012), with the following inclusion criteria: the informants should be Esther coaches; be employed by the municipalities in the Highland district; and have carried out at least one improvement project. These criteria ensured that the informants had experience of both co-production and improvement work in relation to users with complex care needs. An information letter was sent to 99 Esther coaches by email. A total of 12 Esther coaches were included in the study. The first part of the study was conducted by C.Ä. as part of her Master thesis (Ärleskog, 2017). The second part of this study, the development of the reflection model, was done by all three authors who have background in quality improvement in health and welfare. Two of the authors were involved in the Esther Network, C.Ä. as a newly trained Esther coach and N.V. as coordinator of Esther Network international. The third author, A-C.A., is an associate professor in improvement science with experience of theoretical modeling but was not involved in the Esther Network. In this part of the study, the authors elaborated the results from the first part of the study by conceptualizing the results with Franzén's (2010) power triangle.

Data collection. Data were collected through individual qualitative interviews (Kvale and Brinkmann, 2009). The interviews were semi-structured and based on the following themes: user influence, coaching improvement work, and the user's influence in improvement work. The semi-structured approach focused on the topic and, at the same time, provided generous space for the coaches to formulate their answers and narratives (Bryman, 2011). A pilot interview was conducted to validate the guide but did not lead to any changes. The interviews were carried out at the coaches' workplaces $(n=7)$, in public places $(n=2)$, or by telephone $(n=3)$. All informants gave their permission to record their interviews. The interviews took between 30 and $80 \mathrm{~min}$ and were transcribed by the interviewer within 2 days, when the memory of the interviews was fresh (Priebe and Landström, 2012). The transcription was verbatim to manage preunderstanding and to stay close to the empirical data. All informants were offered access to the transcribed text for additions and/or clarifications.

Data analysis and model development. The interviews were initially analyzed by inductive conventional content analysis inspired by Hsieh and Shannon (2005). The verbatim transcription enabled systematic analysis, which strengthened the study's reliability (Wallengren and Henricsson, 2012). Accordingly, the analysis used a deductive directed content analysis approach (Hsieh and Shannon, 2005), in which the statements of the informants were analyzed using perspectives of Franzén's (2010) power triangle. Based on the deductive analysis of the interviews and the dimensions in the power triangle, the authors developed a reflection model. The basis of the model was created in line with and inspired by the theoretical framework of Franzén's (2010) power triangle.

Ethics. Ethical considerations and principles were integrated in the research design to protect the integrity of the informants and their organizations. Before the interview study, informed consent, both written and oral, was obtained; the interviewer provided the informants with accurate information and highlighted that their participation was voluntary and could be withdrawn at any time without consequences (Danielsson, 2012; Kjellström, 2012). No formal ethical review was required for this study because Swedish law does not require ethical approval for interviews with staff concerning work related issues (Lag om Etikprövning [Swedish law of Ethic Regulation], SFS 2003: p. 460).

\section{Results}

The first part of this study investigated the improvement coaches' perceptions of enablers and barriers related to power in coproduction. The coaches had different professions and worked in elderly care or with younger users with cognitive or mental disabilities. Each of the six Highland municipalities were represented. The informants had between 1 and 10 years of experience in the coach role and between 8 and 40 years of work experience in health and/or social care. The results of the empirical study revealed two main categories, power-related "barriers" and "enablers", and four subcategories, described and exemplified with the most common factors below and in Table 1. 
Table 1 The two categories and four subcategories from the data analysis in first part of the study.

\section{Enablers}

Access to resources

The user's resources (health, communication ability, cognitive ability, etc.)

Alternative resources (the social network, the relationship to

caregivers, caregiver's personal knowledge about the user, etc.)

The unit's resources (enough staff, continuity, time, etc.)

The organization's resources (leader's interest and involvement, political and financial support, etc.)

Discursive resistance

The improver strives that the relationship to the user is characterized by equality, humility and empathy.

The improver is opened to change and carries out improvement work without prestige.

\section{Barriers}

No access to resources

Lack of enabling resources
Discursive barriers

Discursive barriers among users (not making demands, lack of confidence, adaptation to contextual factors, subordination to caregivers, etc.)

Discursive barriers among professionals (holding on to old routines, resistance to change and co-production, negative attitudes, lack of trust in user's abilities to contribute, parenting roles, etc.)
The improvement coaches perceived that resources at different levels could have an impact on the ambition of co-production in improvement work. The coaches perceived that the user's resources varied between individuals and clientele. For users with dementia or intellectual disabilities, co-production was considered particularly problematic. Coaches who worked in units with these clients often argued that the users were dependent on others, i.e., alternative resources, to participate in improvement work. The contextual dimension was also highlighted by the coaches' perceptions of the resources necessary for co-production. Regarding the unit's resources, the coaches often described a work situation characterized by understaffing, which resulted in a lack of continuity, high staff turnover, lower degree of quality, and a lack of personal knowledge about the users. As a result of insufficient resources at this level, co-production was also considered too time-consuming. Organizational resources, such as financial resources, were perceived to create conditions whereby extended influence of users was possible. A general perception was that these enabling resources were often insufficient to meet users' expectations and to make real user influence possible. Instead, the lack of resources increased the risk of improvement work merely collecting users' views without the possibility to act on them.

The improvement coaches described attitudes as central when talking about co-production in improvement work. The coaches argued that caregivers sometimes still express a paternalistic care ideology and lacked faith in the user's abilities to contribute. They further perceived that users, especially in elderly care, often subordinate themselves to the caregivers to avoid the risk of being considered as burdens. Discursive barriers were identified both among caregivers and users. The coaches described that they tried to distance themselves from these barriers to strengthen enablers instead by challenging non questioned perceptions and attitudes that preserve asymmetric power relationships between caregivers and user (Table 1). The coaches' perceptions of discursive barriers were not static; they argued that these barriers could be changed and affected by the caregivers. As examples this was considered possible through seeing the user as an active subject, taking the user seriously and really taking the time to listen to the user. To handle the discursive barriers that interfered with co-production, the coaches also meant that improvement work had to be done without prestige. This included actively involving users, asking about their needs and perspectives and value the users' contributions. To enable co-production for users with dementia or intellectual disabilities, the coaches also advocated adapted forms of user participation and using alternative resources (Table 1) based on the user's ability. The examples above illustrate discursive resistance, or in other words strategies that were considered to balance power and handle the discursive barriers that interfered with co-production. However, the coaches reasoned that the barriers could be hard to overcome given the contextual factors. For example, the coaches suggested that users' awareness about the unit's resources could result in further adaptation. To conclude, the improvement coaches highlighted several powerrelated factors in all three power dimensions. These factors and the interaction between the dimensions were considered to affect the conditions for co-production in improvement work. Coproduction then requires focus on more than one power dimension, for example available resources.

In the second part, the results from part one were further elaborated as we developed a reflection model, taking all dimensions into consideration. To make the model user friendly, each dimension contains concrete factors identified in the empirical part of the study; factors that can be transferred and adjusted to other contexts. An important part of the model development was that we wanted to promote action and learning by reflection. The triangle was supplemented with a three-step cycle towards action (see Fig. 2). The first step is about reaction, which stimulates the improver to identify and react upon barriers and enablers of co-production within the inner triangles (power dimensions). To react one needs to be aware of a situation, such as possible barriers as attitudes against co-production. The next step, interaction, guides the improver towards deeper reflection. It is an essential part of co-production because one cannot coproduce if there is no interaction in place. Further, interaction is important to consider in relation to discourses, resources, and contexts. It reminds the improver to reflect upon the interaction between the power dimensions, which supports parallel discussions about the dimensions. The third step is action. The improver then moves from reflection to action to either handle barriers or reinforce the enablers. Action requires awareness of the three parts in the triangle.

The power triangle of co-production is proposed as a reflection model for improvers of health and social care to enable more symmetric co-production. Reflection can help minimize the barriers and increase the enablers if used regularly in health and welfare organizations.

\section{Discussion}

This paper addresses the challenge of co-production related to power and suggests a reflection model to balance power conditions. Based on the interviews, the study highlights that the users' influence in improvement work depends on power. The conditions for co-production can then be regarded as a relative 


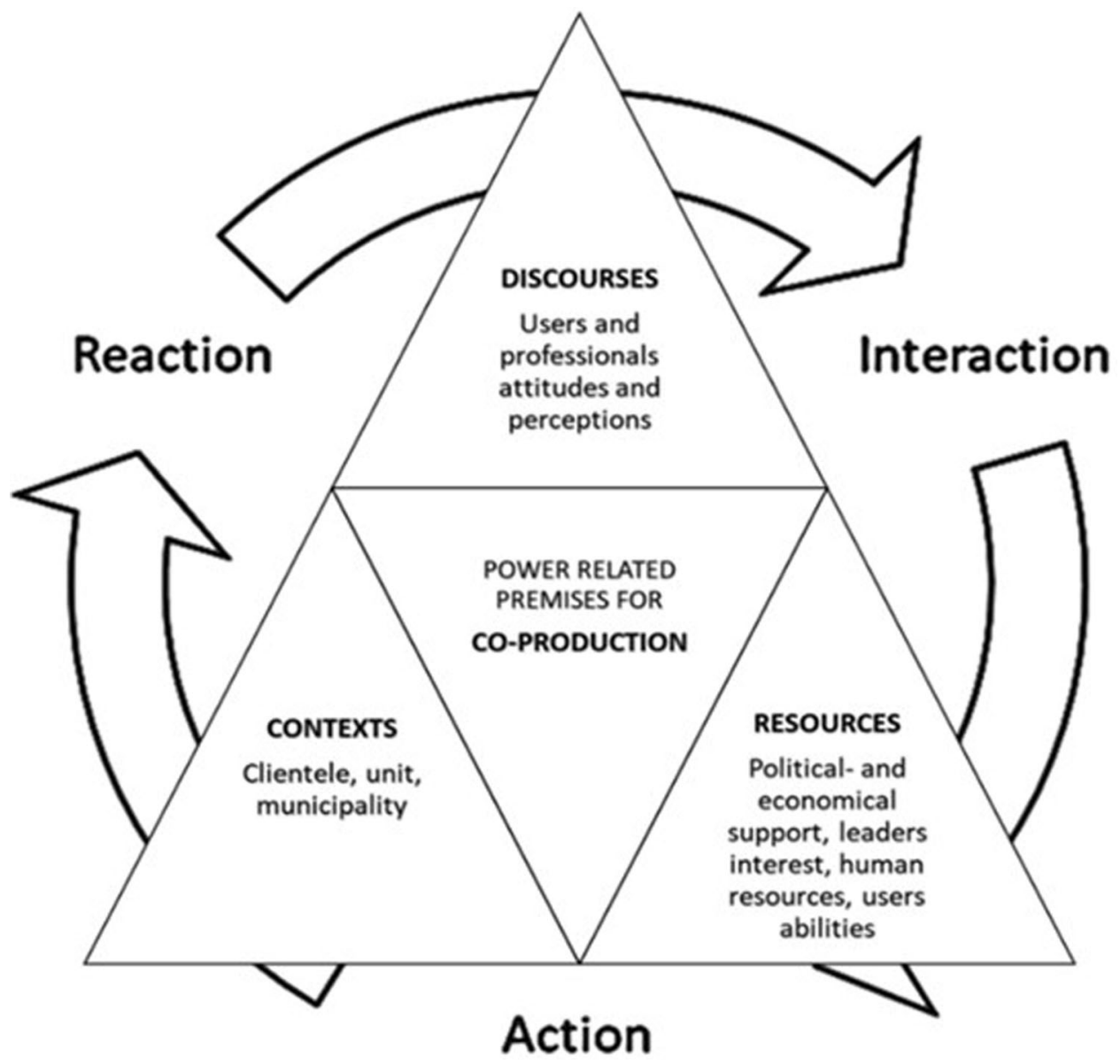

Fig. 2 The power triangle of co-production. Created by authors.

phenomenon that can change over time (Franzén, 2010). This means that it is possible to balance power when co-producing health and welfare services; a crucial opportunity in light of growing research highlighting how user involvement is a key for making custom-tailored improvements (Armitage et al., 2018; Baim-Lance et al., 2016; Coulter, 2012; Roseman et al., 2013). Vuong and Napier (2015) pointed out that changing mindsets are difficult and can only be achieved by repeating and continuously squeezing out inappropriate values and absorb new ones that fit the context better, called the mind sponge mechanisms. A first step can be by creating awareness with a reflection model. We claim that it is necessary to build in structured reflection about power dimensions to increase the level of user influence. A constant awareness, reflective practice, and dialog are essential to facilitate a more balanced relational process and to institute changes at both an individual and organizational level. (Farr, 2018; Vuong et al., 2018).

The power triangle in co-production has a strong theoretical approach and recognizes central dimensions within relational power theory. Thompson and Pascal (2012) argue that reflection has become oversimplified and often lacks a theoretical connection considered necessary in relation to care. Our model is built on both a theoretical base and empirical data: the power triangle of Franzén (2010) and experiences and perspectives of improvement coaches within health and social care. A supportive factor in the model is the balance between structure and freedom. The power triangle in co-production has a systematic character, but at the same time allows the improver to adjust to the power dimensions within their own specific context. Reflection models often have too much structure, which is associated with the risk of linear thinking and automatic and predefined answers. This contrasts with the purpose of reflection, which aims to create deeper understanding and insight. A deeper understanding, including different perspectives, is important to avoid unquestioned routines, and instead be able to highlight factors that otherwise could remain unspoken (Pettersson, 2015). However, since the character of co-production is relative, the dimensions in the model cannot be handled or discussed separately; they are interdependent. A critical approach is then recommended when using the model because resistance does not need to be conscious or active (Franzén, 2010). The model is therefore supplemented with a cycle to highlight the interaction between the power dimensions and stimulate action on the power dimension in the development of co-production. For example, the improver might have to stimulate changed attitudes among colleagues to enable alternative resources and through this create better conditions for co-production. When one cycle is completed, the process continues with "reaction" to systematically highlight barriers and enablers. In that way, new insights can raise the level of coproduction.

The first part of this study is based on the perceptions of improvement coaches specially trained to co-produce improvements. These coaches and other improvers in health and social care are important because they can use their power to block or promote user influence (Roos, 2009). However, even if professionals automatically have power when they represent an organization (Skau, 2007), this power cannot be understood independently of the organization (Persson and Berg, 2009). According to the coaches, the units and/or the organization's resources are often limited, which is counterproductive because 
successful co-production in quality improvement requires organizational support (Bergerum et al., 2019). Secondary relationships, such as the professionals' relationship towards the organization, can then affect power relations (Franzén, 2010), which is notable because co-production involves multiple relationships among clients and stakeholders. However, stakeholders can experience a conflict of values and can also have access to various forms of power resources (Lundgren, 2013), an insight that highlights a connection between resources and contexts (Franzén, 2010). Power dimensions cannot be understood without taking the organizational context into account. We therefore recommend that an influence perspective should permeate the organization at all levels (Lindquist, 2007). To achieve this will also require a reflection at an overall organizational level, for example in terms of resources and how to organize care to enable co-production. The coaches further reported that discursive barriers could be maintained by users' doubts concerning how they could contribute to improvement work. This result corresponds to how discourses permeate power relationships and affect our identity (Franzén, 2010). If there are discursive barriers shaped and upheld by caregivers, it is not surprising that those barriers could also affect how users think about themselves and their own abilities, which underlines the importance of continuous reflection and dialog about user influence (Söderlund and Gentzel, 2007). On the other hand, not every user has the desire to be an active participant in co-production (Osborne et al., 2016). Sometimes the user is too sick and in need of professionals to make decisions (Batalden et al., 2016). It is therefore important for improvement coaches and other improvers of health and social care to consider how they use their power and if the use of their power is in the best interest of users with complex care needs.

We chose to interview improvement coaches in the Esther Network because they are supposed to co-produce improvements. This can be a limitation of the study because their experiences of enablers and barriers in the co-production process are related to their context. If we had interviewed leaders in health and social care, we would most likely been given a different perspective. Studying power balance as a key factor in co-production from an organizational and more economical perspective would be of interest for future studies. We still argue that the potential in the reflection model would benefit widely; it is not a descriptive model but a model that invites reflection regardless of context. The Esther Network has spread to other countries, including Singapore, Austria, and Denmark, and they face similar challenges in relation to coproduction irrespective of care being organized differently in these countries. Therefore, there is reason to believe that the model can be generic and useful for professionals with the ambition to improve health and social care for and with its users, regardless of the users' health status and care needs. The model should not be understood as a rigid template but as an inspiration to act on power imbalances when necessary. Another limitation could be that the model was not developed in co-production with users in health and social care. We suggest this reflection model as a tool to raise awareness about power relationships and act upon them. A next step will be to test the reflection model within the training for Esther coaches, thereby developing the model further and including users and their perspective. As previously stated, co-production in relation to improvement work is complex. We therefore hope that the power triangle in co-production can contribute to support co-production on more equal terms. It could be interesting to explore if users are more willing to co-produce when power reflections are addressed as a natural part of the co-production process. Our reflection model can be one way to do this.

\section{Conclusions}

This study offers insights about how power dimensions affect the conditions for co-production in improvement work within health and social care. The authors propose a reflection model, the power triangle of co-production, that can be used to balance power and create a more symmetric relationship in coproduction. The reflection model can be useful in several contexts because it has a flexible and non-prescriptive character. We believe that the power triangle in co-production can be an inspiration for improvers in health and social care when developing co-produced improvement work.

\section{Data availability}

Data that supports the findings of this study are available from the corresponding author upon reasonable request.

Received: 4 January 2020; Accepted: 9 April 2021;

Published online: 07 May 2021

\section{References}

Ärleskog C (2017) Brukarinflytandets komplexitet. Master thesis. Jönköping University, Jönköping. [in Swedish]

Armitage G, Moore S, Reynolds C, Laloë P-A, McEachan R, Lawton R, Watt I, Wright J, O'Hara J (2018) Patient-reported safety incidents as a new source of patient safety data: an exploratory comparative study in an acute hospital in England. J Health Serv Res Policy 23(1):36-43

Arnstein S (1969) A ladder of citizen influence. J Am Inst Planners 4:216-224

Bagchus C, Dedding C, Bunders JG (2015) I'm happy I can still walk-influence of the elderly in home care as specific group with specific needs and wishes. Health Expect 18(6):2183-2191

Baim-Lance A, Tietz D, Schlefer M, Agins B (2016) Healthcare user perspectives on constructing, contextualizing, and co-producing 'quality of care'. Qual Health Res 26(2):252-263

Batalden P (2018) Getting more health from healthcare: quality improvement must acknowledge patient coproduction-an essay by Paul Batalden. BMJ Qual Saf 362:k3617

Batalden M, Batalden P, Marholis P, Seid M, Armstrong G, Opipari-Arrigan L, Hartung $H$ (2016) Coproduction of healthcare service. BMJ Qual Saf 25:509-517

Bergerum C, Thor J, Josefsson K, Wolmesjö M (2019) How might patient involvement in healthcare quality improvement efforts work-a realist literature review. Health Expect 22:952-964

Biguet G, Ekstrand-Sporre Å, Thörne K (2015) Att utvecklas genom att reflektera tillsammans i grupp. In: Biguet G, Lindqvist I, Martin C, Pettersson A (eds) Att lära och utvecklas i sin profession. Studentlitteratur, Lund, pp. 123146. [in Swedish]

Bovaird T (2007) Beyond engagement and influence: user and community coproduction of public services. Public Admin Rev Sept/Oct 67(5):846-860

Boyle D, Harris M (2009) The challenge of co-production. How equal partnerships between professionals and the public are crucial to improving public services. Discussion Paper, Nesta, www.neweconomics.org

Bryman A (2011) Samhällsvetenskapliga metoder, 2nd edn. Liber, Malmö, [in Swedish]

Central Bureau of Statistics (2019) Folkmängd i riket, län och kommuner 31 mars 2019 och befolkningsändringar 1 januari-31 mars 2019 (Internet): Available from: https://www.scb.se/hitta-statistik/statistik-efter-amne/befolkning/befolkningenssammansattning/befolkningsstatistik/pong/tabell-och-diagram/kvartals--ochhalvarsstatistik--kommun-lan-och-riket/kvartal-1-2019/ [in Swedish]

Cohglan D, Brannick T (2001) Doing action research in your own organization. SAGE Publications, Thousand Oaks, CA

Coulter A (2012) Patient engagement-what works? J Ambul Care Manag 35 (2):8089

Danielsson E (2012) Kvalitativ forskningsintervju. In: Henricsson M (ed) Vetenskaplig teori och metod. Studentlitteratur, Lund, pp. 163-173. [in Swedish]

Dewey J (1997) How we think. Dover Publications, New York, NY

Farr M (2018) Power dynamics and collaborative mechanisms in co-production and co-design processes. Crit Soc Policy 38(4):623-644

Franzén M (2010) I fråga om makt. Diskurser, resurser, kontexter. In: Goldberg T (ed) Samhällsproblem, 7th edn. Studentlitteratur, Lund, pp. 85-121. [in Swedish]

Gibbs G (1988) Learning by doing: a guide to teaching and learning methods. Further Education Unit, Oxford Brookes University, Oxford 
Giertz L (2012) Erkännande, makt och möten-en studie av inflytande och självbestämmande med LSS. Doctoral thesis, Linnéuniversitetet, Växjö. [in Swedish]

Glouberman S, Zimmerman B (2002) Complicated and complex systems: what would successful reform of Medicare look like? Discussion Paper No. 8, Commission on the future of health care in Canada

Godfrey M, Andersson Gare B, Nelson EC, Nilsson M, Ahlström G (2013) Coaching interprofessional health care improvement teams: the coachee, the coach and the leader perspectives. J Nurs Manag 22(4):452-464

Greenhalgh T, Humphrey C, Woodard F (2011) User involvement in health care. John Wiley, Chichester

Harnett T, Jönsson H, Wästerfors D (2012) Makt och vanmakt på äldreboenden. Studentlitteratur, Lund, [in Swedish]

Henricsson M, Billhult A (2012) Kvalitativ design. In: Henricsson M (ed) Vetenskaplig teori och metod. Studentlitteratur, Lund, pp. 129-138. [in Swedish]

Hsieh H-F, Shannon SE (2005) Three approaches to qualitative content analysis. Qual Health Res 15(9):1277-1288

Karlsson M, Börjesson M (2011) Brukarmakt-i teori och praktik. Natur \& Kultur, Stockholm, [in Swedish]

Kirkegaard S, Andersen D (2018) Co-production in community mental health services. Socio Health Illn 40(5):828-842

Kjellström S (2012) Forskningsetik. In: Henricsson M (ed) Vetenskaplig teori och metod. Studentlitteratur, Lund, pp. 69-94. [in Swedish]

Kvale S, Brinkmann S (2009) Den kvalitativa forskningsintervjun, 2nd edn. Studentlitteratur, Lund, [in Swedish]

Lag om etikprövning av forskning som avser människor [Swedish law of Ethic Regulation] (SFS 2003:460) Ministry of Health and Social Affairs, Stockholm, Sweden. [in Swedish]

Lilja M, Vinthagen S (2009a) Maktteorier. In: Lilja M, Vinthagen S (eds) Motstånd. Liber, Malmö, pp. 27-43. [in Swedish]

Lilja M, Vinthagen S (2009b) Motståndsteorier. In: Lilja M, Vinthagen S (eds) Motstånd. Liber, Malmö, pp. 47-88. [in Swedish]

Lindquist A-L (2007) Att främja inflytande för psykiskt sjuka och funktionshindrade-ett utvecklingsarbete inom vård och omsorg: Utvärdering av tio försök med brukarinflytandesamordnare (BISAM) i kommun och landsting. Socialhögskola, Stockholm. [in Swedish]

Lundgren M (2013) Framtiden är inte längre vad den har varit. Vulkan, Stockholm. [in Swedish]

Moon J (2004) A handbook of reflective and experiential learning: theory and practice. Routledge, London

Mulvale G, Moll S, Miatello A, Robert G, Larkin M, Palmer VJ, Powell A, Gable C, Girling M (2019) Co-designing health and other public services with vulnerable and disadvantaged populations: insights from an international collaboration. Health Expect 22(3):284-297

Norman A-C (2015) Towards the creation of learning improvement practices. Studies of pedagogical conditions when change is negotiated in contemporary healthcare practices. Doctoral thesis, Linnéuniversitetet, Växjö

Osborne PS, Radnor Z, Strokosch K (2016) Co-production and the co-creation of value in public services. A suitable case for treatment? Public Manag Rev 18 (5):639-653

Persson T, Berg S (2009) Older people's "voices"-on paper: obstacles to influence in welfare states-a case study of Sweden. J Aging Soc Policy 21(1):94-111

Pettersson A (2015) Reflektion-en del av lärandet. In: Biguet G, Lindqvist I, Martin C, Pettersson A (eds) Att lära och utvecklas i sin profession. Studentlitteratur, Lund, pp. 39-52. [in Swedish]

Priebe G, Landström C (2012) Den vetenskapliga kunskapens möjligheter och begränsningar-grundläggande vetenskapsteori. In: Henricsson M (ed) Vetenskaplig teori och metod. Studentlitteratur, Lund, pp. 31-52. [in Swedish]

Roos C (2009) Delaktighet inom äldreomsorgen: Om att låta de äldre få behålla makten över sina liv. Vårdförlaget. [in Swedish]

Rose D, Kalathil J (2019) Power, privilege and knowledge: the untenable promise of co-production in mental "health". Front Sociol 4:57

Roseman D, Osborne-Stafsnes J, Helwig C, Boslaugh S, Slate-Miller S (2013) Early lessons from four 'aligning forces for quality' communities bolster the case for patient-centered care. Health Affairs 32(2):232-241

Schön D (1983) The reflective practitioner. Jossey Bass, San Francisco, CA
Skau G-M (2007) Mellan makt och hjälp. 3 edn. Liber, Malmö. [in Swedish] Söderlund B, Gentzel L (2007) Patienter som konsulter i vården. Available from: http://www.socialstyrelsen.se/psykiskohalsa/nationell-psykiatrisamordning 2005-2007/Documents/Patientersomkonsulterivarden.pdf [in Swedish]

The National Board of Health and Welfare (2008) Vård och omsorg om äldre-Lägesrapport 2008. Artikelnr 2009-12644. [in Swedish]

The National Board of Health and Welfare (2011) Metoder för brukarinflytande och medverkan inom socialtjänst och psykiatri-en kartläggning av forskning och praktik. Artikelnr 2011-12-20. [in Swedish]

The National Board of Health and Welfare (2013) Att ge ordet och lämna plats. Vägledning om brukarmedverkan och inflytande inom socialtjänst, psykiatri och missbruks- och beroendevård. Artikelnr 2013-2-9. [in Swedish]

Thompson N, Pascal J (2012) Developing critically reflective practice. Reflect Pract 13(2):311-325

Thor J, Wittlov K, Herrlin B, Brommels M, Svensson O, Skar J, Ovretveit J (2004) Learning helpers: how they facilitated improvement and improved facilitation-lessons from a hospital-wide quality improvement initiative. Qual Manag Health Care 13(1):60-74

UCL Public Engagement Blog (2020) Fake involvement is not enough: https:// blogs.ucl.ac.uk/public-engagement/2020/08/14/diagnostic-odyssey/

Vackerberg N, Sund Levander M, Thor J (2016) What is best for Esther? Building improvement coaching capacity with and for users in health and social care-a case study. Qual Manag Health Care 25(1):53-60

Vindrola-Padros C, Eyre L, Baxter H, Cramer H, George B, Wye L, Fulop N, Utley M, Phillips N, Brindle P, Marshall M (2019) Addressing the challenges of knowledge co-production in quality improvement: learning from the implementation of the researcher-in-residence model. BMJ Qual Saf 28:67-73

Vuong QH, Napier NK (2015) Acculturation and global mindsponge: an emerging market perspective. Int J Intercult Relat 49(1):354-367

Vuong QH, Ho TM, Nguwen HK, Vuong TT (2018) Health consumers' sensitivity to costs: a reflection on behavioral economics from an emerging market. Palgrave Commun 4:70

Wallengren C, Henricsson M (2012) Vetenskaplig kvalitetssäkring av litteraturbaserat examensarbete. In: Henricsson M (ed) Vetenskaplig teori och metod. Studentlitteratur, Lund, p. 481495. [in Swedish]

\section{Competing interests}

The authors declare no competing interests.

\section{Additional information}

Correspondence and requests for materials should be addressed to C.Är.

Reprints and permission information is available at http://www.nature.com/reprints

Publisher's note Springer Nature remains neutral with regard to jurisdictional claims in published maps and institutional affiliations.

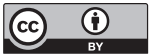

Open Access This article is licensed under a Creative Commons Attribution 4.0 International License, which permits use, sharing, adaptation, distribution and reproduction in any medium or format, as long as you give appropriate credit to the original author(s) and the source, provide a link to the Creative Commons license, and indicate if changes were made. The images or other third party material in this article are included in the article's Creative Commons license, unless indicated otherwise in a credit line to the material. If material is not included in the article's Creative Commons license and your intended use is not permitted by statutory regulation or exceeds the permitted use, you will need to obtain permission directly from the copyright holder. To view a copy of this license, visit http://creativecommons.org/ licenses/by/4.0/.

(C) The Author(s) 2021 